\section{Policy Research Wo
Trade, Migration, and Welfare}

The Impact of Social Capital

Maurice Schiff

\section{WPS 2044}

2044
The South gains by freeing trade and the North by restricting immigration. The South should liberalize trade, and the North should impose an immigration tax.

The World Bank

Development Research Group

Trade

January 1999 
Policy Research Working Paper 2044

\section{Summary findings}

Despite the predictions of standard trade theory, countries in the North are not indifferent about free migration and free trade. Migration has become a major concern in some OECD countries. But is migration really a threat? If tree trade is optimal, shouldn't free migration be optimal as well? Why do so many countries advocate free trade but restrictions on international migration?

Wellisch and Walz (1998) have shown that there is no inconsistency in advocating free trade at the same time as restricting migration under redistributive policies in the rich countries. Schiff argues that this holds in the presence of social capital as well. South-North migration affects social capital in both places.

The movement of people differs from the movement of goods and services in that people create attachments with those with whom they share social capital (including norms, language, customs, values, and culture) and interact with them at lower cost. So migration generates externalities.

Schiff identifies four types of externalities associated with migration. He examines the impact of trade and migration policies under alternative assumptions about internalizing these externalities and concludes that the South always gains by freeing trade and the North by controlling immigration.

These policy recommendations improve the distribution of income by improving the welfare of labor relative to that of capital. Trade liberalization in the South results in higher wages (and social capital) and lower returns to capital. An immigration tax in the North has no impact on capital, but labor gains from collecting the tax (and from higher social capital).

This paper - a product of Trade, Development Research Group - is part of a larger effort in the group to understand the links between migration and trade. Copies of the paper are available free from the World Bank, $1818 \mathrm{H} \mathrm{Street} \mathrm{NW,}$ Washington, DC 20433. Please contact Lili Tabada, room MC3-333, telephone 202-473-6896, fax 202-522-1159, Internet address ltabada@worldbank.org. The author may be contacted at mschiff@worldbank.org. January 1999. (27 pages)

The Policy Research Working Paper Series disseminates the findings of work in progress to encourage the exchange of ideas about development issues. An objective of the series is to get the findings out quickly, even if the presentations are less than fully polished. The papers carry the names of the authors and should be cited accordingly. The findings, interpretations, and conclusions expressed in this paper are entirely those of the authors. They do not necessarily represent the view of the World Bank, its Executive Directors, or the countries they represent. 


\title{
Trade, Migration and Welfare: The Impact of Social Capital
}

\author{
Maurice Schiff* \\ Development Economics Department \\ The World Bank
}

\begin{abstract}
Despite the predictions of standard trade theory, countries in the North are not indifferent between free migration and free trade. Explanations include the redistributive policies of the welfare state (Wellisch and Walz, 1998, this Review). This paper offers an explanation using the concept of social capital and extends the analysis to the South. The movement of people differs from the movement of goods and services because people create attachments with those with whom they share social capital, including norms, language, customs, values and culture. South-North migration affects social capital in both places. Four types of externalities associated with migration are identified. The paper examines the impact of trade and migration policies under alternative assumptions about internalization of these externalities, and concludes that the South always gains by freeing trade and the North by controlling immigration.

JEL classification numbers: F11, F13, F22, J61.
\end{abstract}

Keywords: migration, social capital, welfare.

* The author would like to thank Guillermo Calvo, Arvind Panagariya, Tony Venables and seminar participants at Columbia, Maryland, Namur, the Catholic University of Chile and the World Bank Trade Seminar and Macroeconomics Seminar, for their useful comments. 


\section{Trade, Migration and Welfare: The Impact of Social Capital}

\section{Introduction}

Migration has become a major issue of concern in a number of $\mathrm{OECD}$ countries. In various $\mathrm{EU}$ member countries, including France and Austria, parties advocating strong restrictions on immigration have made important gains in recent years. The same phenomenon is found in Australia. In California, voters recently endorsed Proposition 187 which would deny non-emergency public services to illegal immigrants, and the U.S. Congress has considered legislation which would significantly reduce legal immigration. ${ }^{1}$ And Canada has put in place programs designed to ensure that immigrants bring sufficient human, financial and/or entrepreneurial capital with them (Stalker 1994).

In addition to immigration policy, destination countries have considered using trade policy to deal with migration. For instance, during the debate on NAFTA, Presidents Salinas and Bush argued that NAFTA would help Mexico export more goods and fewer people, thereby reducing the migration 'threat'. Similarly, in the context of the concern with massive emigration from the East, then-Germany's Foreign Minister Kinkel declared that opening West European markets should be a priority in a new initiative on a common European 'ostpolitik' (Financial Times, March 24, 1994). ${ }^{2}$

But is migration really a 'threat'? In other words, if free trade is optimal, should free migration not be optimal as well? A number of politicians and economists have addressed this issue and have taken the

\footnotetext{
${ }^{1}$ The issue of the net costs and benefits of immigration to the U.S. has been examined in a number of studies (e.g., Borjas, Freeman and Katz 1992; Borjas 1993, 1995b).

${ }^{2}$ These statements are based on the assumption that trade liberalization reduces migration, i.e., that trade and migration are substitutes. Substitution obtains in the Heckscher-Ohlin model, while complementarity is obtained by Markusen (1983) in the case of economies of scale and sector-specific technological difference. Schiff (1995) obtains complementarity in the Heckscher-Ohlin model with migration costs and financing constraints, while substitution is obtained for skilled labor and complementarity for unskilled labor in Lopez and Schiff (1998). Faini and Venturini (1993) find complementarity between income and migration from Southern to Northern Europe at low levels of income and substitution at higher levels. The 'Ricardian' Heckscher-Ohlin model developed in this paper implies substitution between trade and migration.
} 
seemingly inconsistent position of advocating free trade while also advocating restrictions on international migration. Bhagwati (1991) argues that this inconsistency is “ ... due to the lack of consistent criteria by which the two issues are judged and decided" (p. 3), and that applying the utilitarian logic to the problem of migration leads to the free migration solution (pp. 5,6). Wellisch and Walz (1998, this Review) have shown that there is no inconsistency in advocating free trade as well as restrictions on migration under redistributive policies in the rich countries. This paper shows that this holds in the presence of social capital as well.

The concept of social capital was first introduced by Coleman $(1987,1988,1990)$. Social capital can be defined as "... the set of elements of the social structure that affect relations among people and are inputs or arguments of the utility and/or production function" (Schiff, 1992a). These elements include social norms, attitudes, values, language and culture. Social capital in the form of close ties to family and community may generate benefits by raising utility and by raising output (by reducing the cost of transacting business due to higher trust and enforceability of sanctions).

Several papers have examined the impact of some aspects of social capital on the accumulation of human capital. Coleman (1988) studied the impact of family structure. Borjas (1992) showed that ethnicity acts as an externality which slows the convergence of human capital across ethnic groups over time. He further shows that ethnic capital is closely linked to ethnic neighborhoods (Borjas, 1995a). He concludes that further issues to be examined include the effects of interactions among ethnic groups. One such interaction which is examined here is that resulting from international migration.

Evidence on the impact of social capital on migration is limited. Cashin and Sahay (1996) examine the determinants of migration across Indian states. They find that income in the destination state has a much smaller impact on inter-state migration in the period 1961-1991 than found in studies of migration across U.S. states in 1900-1987 or across prefectures in Japan in 1955-1985. The impact of income in the destination state on migration in India is closer to that for migration across regions of Europe. The authors argue that the most important factors explaining the difference in response in the U.S. and Japan on the one hand, and Europe and 
India on the other, are the higher level of social, cultural and linguistic barriers in the latter. Similarly, Faini and Venturini (1993) state that "... cultural, social and linguistic differences ... may at least partly account for much lower labor mobility in Europe than in the U.S." Thus, it seems safe to assume that these barriers which play a significant role in North-North (Europe) and South-South (India) migration - are likely to play an important role in South-North migration as well.

Katz and Stark (1987) examine international migration in the presence of informational asymmetries. They conclude that the impact of migration on social attitudes may be of great importance and should be incorporated if the theory is to be of use for policy analysis. This is what this paper intends to do. ${ }^{3}$ I examine the consequences of migration policy for migration, social capital, income and welfare of the various groups. Trade policy, migration costs, remittances and illegal migration are also examined.

Trefler (1995) shows that the model which best explains trade flows is a modified Heckscher-Ohlin model with neutral technological differences and Armington-type home bias in consumption. Davis and Weinstein (1997) compare the Heckscher-Ohlin model of comparative advantage with that of economic geography in order to explain the structure of OECD manufacturing production, and find that the former explain 90 percent, the latter only percent. And if this is true for the OECD, it is likely to hold even more strongly between the North and the South. ${ }^{4}$ Hence, the basic framework used here is the Heckscher-Ohlin

\footnotetext{
${ }^{3}$ Recent work - some of which is surveyed in Borjas (1994) - has improved our understanding of migration behavior. Stark (and colleagues) has made seminal contributions in the field, some of which are collected in his 1991 volume. These include the analysis of the impact on migration of a desire to diversify family risk, of financial market imperfections, and of the relationship between migration on the one hand, and the demand for children, investment in their human capital and the motive to remit on the other. Group features of migration - which are central to our analysis - are also examined in that volume, including relative deprivation where utility also depends on how individual income relates to the income of others in the individual's reference group. Group effects are also present in Galor and Stark (1990) who examine the effect of differential rights and incentives faced by immigrant groups and natives. Using the same model, Schaeffer (1995) adds differences in degrees of assimilation, and Djajic and Milbourne (1988) compare migrants' behavior in the host country with their behavior after they return home. Group features of migration in an endogenous growth framework are present in Barro and Sala-i-Martin 1992, 1995; Borjas 1992, 1995a; Galor and Stark 1994; and Haque and $\operatorname{Kim} 1995$.
}

${ }^{4}$ Note also that in the case of Canada, Balistreri (1997) found that agents' views on the distributional effects of trade liberalization are consistent with the predictions of the Heckscher-Ohlin model. 
model, but with three additional features: a higher level of technology in the North than in the South, international migration, and social capital. This model abstracts from aspects of migration described in footnote 3 and from economies of scale and imperfect competition. ${ }^{6}$

The analysis is carried out under two behavioral assumptions: either the emigrants maximize individual utility with no concern for the welfare of others, or migration is part of a collective welfare maximization process in which all migration externalities for emigrants and non-emigrants of the South are internalized. In reality, migrants internalize some externalities (e.g., with respect to their family and friends) but probably not all. By examining the implications of the model under the two extreme assumptions of zero and full internalization, we can verify which results are robust and focus on them. Social capital can be thought of as affecting utility directly and/or indirectly through its effect on production. Following Becker (1996) and Schiff (1992a), I assume that social capital enters the utility function. Bliss (1994) makes a similar assumption. He states that migration may generate externalities through its effect on the survival of local cultures and life-styles. Others (e.g., Coleman 1988, Putnam 1993) have modeled social capital on the production side. ${ }^{7}$ Making the latter assumption complicates the analysis but does not affect the main findings. However, an important difference is that internalization of the externalities associated with social capital is less likely to occur in the case where social capital enters the production function (see Section 5).

\footnotetext{
${ }^{5}$ In the phraseology of Dixit and Norman (1980, p. 148), a two-country model where one country has a general technological advantage and where each country's comparative advantage depends on relative factor endowments is referred to as a 'Ricardian' Heckscher-Ohlin model.

${ }^{6}$ Analysis of trade policy under imperfect competition can be found in Helpman (1984), Markusen and Venables (1988), Rodrik (1988) and Venables (1985). Factor mobility under imperfect competition is examined in Ruffin (1984). See also papers in the Symposium on International Factor Mobility in the May 1983 issue of the JIE.

${ }^{7}$ Group effects in Borjas (1992, 1995a), Galor and Stark (1994) and Haque and Kim (1995) also arise on the production side.
} 
Migration policy has generally been considered to be an issue for receiving countries, not for sending countries. ${ }^{8}$ The asymmetry in the treatment of emigration and immigration has its basis in international law. Emigration is considered to be a basic human right established in the U.N. Universal Declaration of Human Rights, while the right of immigration is not recognized by international law. Consequently, migration policy is only considered here from the receiving country's viewpoint.

The remainder of the paper is organized as follows. The model is presented in Section 2. Welfare implications of free migration and of the total restriction of migration are derived in Section 3. Section 4 analyzes the properties and effects of an optimal immigration policy by the receiving North, including the effect of illegal immigration. Sections 3 and 4 also examine the effects of trade policy and of a reduction in migration costs. Section 5 presents concluding comments and suggestions for future research. The results are summarized in Table 1.

\section{The Model}

Assume two small open economies, North $(\mathrm{N})$ and South $(\mathrm{S})$, producing two goods i $(\mathrm{i}=1,2)$, and whose terms of trade are determined on the world market. The goods are produced with two factors, labor (L) and capital $(\mathrm{K})$, under a concave constant-returns-to-scale technology. The North and the world are technologically more advanced than the South. The technological advantage is assumed to be Hicks-neutral and the same in both sectors. Output $\mathrm{Q}_{\mathrm{i}}$ of good $\mathrm{i}$ is

$$
\begin{aligned}
& \mathrm{Q}_{\mathrm{i}}^{\mathrm{s}}=\mathrm{f}_{\mathrm{i}}\left(\mathrm{K}_{\mathrm{i}}^{\mathrm{s}}, \mathrm{L}_{\mathrm{i}}^{\mathrm{s}}\right) ; \mathrm{i}=1,2 ; \mathrm{s}=\text { South, } \\
& \text { (1) } \mathrm{Q}_{\mathrm{i}}^{\mathrm{n}}=\lambda \mathrm{f}_{\mathrm{i}}\left(\mathrm{K}_{\mathrm{i}}^{\mathrm{n}}, \mathrm{L}_{\mathrm{i}}^{\mathrm{n}}\right), \lambda>1 ; \mathrm{i}=1,2 ; \mathrm{n}=\text { North, and } \\
& \partial \mathrm{f}_{\mathrm{i}}\left(\mathrm{K}_{\mathrm{i}}^{\mathrm{j}}, \mathrm{L}_{\mathrm{i}}^{\mathrm{j}}\right) / \partial \mathrm{L}_{\mathrm{i}}^{\mathrm{j}} \rightarrow \infty(\rightarrow 0) \text { as } \mathrm{L}_{\mathrm{i}}^{\mathrm{j}} / \mathrm{K}_{\mathrm{i}}^{\mathrm{j}} \rightarrow 0(\rightarrow \infty) ; \mathrm{j}=\mathrm{s}, \mathrm{n} \text { [Inada conditions]. }
\end{aligned}
$$

The South (North) is abundant in labor (capital) relative to the world. Thus, the North has an absolute

\footnotetext{
${ }^{8}$ Exceptions include Bhagwati $(1972,1976)$ where an emigration tax by the South is proposed in the context of the brain drain problem, Djajic and Milbourne (1988), and Baldwin and Venables (1994).
} 
advantage in the production of both goods relative to the South and a comparative advantage in the production of the capital-intensive good 1 , while the South has a comparative advantage in the production of the laborintensive good 2. Both labor and capital are mobile intersectorally but only labor is mobile internationally. Under free trade, the prices of goods 1 and 2 and the wages $W_{n}$ and $W_{s}$ in the North and South are given by (2) $\mathrm{P}_{\mathrm{in}}=\mathrm{P}_{\mathrm{is}}=\mathrm{P}_{\mathrm{i}}^{*}(\mathrm{i}=1,2), \mathrm{W}_{\mathrm{n}}=\mathrm{W}^{*}=\lambda \mathrm{W}_{\mathrm{s}}>\mathrm{W}_{\mathrm{s}}$,

where the asterisk indicates world prices. Thus, factor price equalization holds under free trade per unit of effective labor.

Migration is concentrated while trade is not. That is, the North and the South trade in the world market but migration only takes place between the two of them. For instance, Mexico (Morocco) (Turkey) trades with the entire world but its citizens emigrate essentially to the U.S. (France) (Germany). ${ }^{9}$ I examine the impact of policies on migrants and on both labor and capital in the North and South.

Assume that all individuals have the same indirect utility function $\mathrm{U}$, which is given by

(3') $U_{j}=U\left(Y_{j}, P_{1 j}, P_{2 j} ; S K_{j}\right) ; j=s, m$ (migrants), $n$,

with $U$ increasing in income $Y$ and in social capital SK and decreasing in $P_{1}$ and $P_{2}$, and with negative second derivatives. Assume for simplicity that $U$ is separable and can be written as

(3) $U_{j}=X\left(Y_{j}, P_{1 j}, P_{2 j}\right)+Z\left(S K_{j}\right) ; j=s, m, n$,

where $\mathrm{X}$ is the component of welfare which is considered in the national accounts. ${ }^{10}$

How does migration affect the level of social capital in the various groups? I assume that most people have a positive preference for associating with those who share the same customs, values, language and culture. This is supported by evidence from the U.S. and the EU that most immigrants are not distribeted

\footnotetext{
${ }^{9}$ The assumptions, that migration only takes place between the South and North, and that the South and North are small (so that their terms of trade are given exogenously), allow us to abstract from the other countries. Extending the analysis to more countries is discussed in Section 5 .

10 Note that policies which raise X need not raise welfare. For instance, Schiff (1992a) has shown that a policy or technological change resulting in an increase in labor mobility and income may be immiserizing due to externalities associated with social capital.
} 
randomly across the receiving country. Rather, immigrants from a given country tend to cluster in specific cities and neighborhoods in order to benefit from the common social capital. For instance, in the U.S., immigrant neighborhoods include Little Havana in Miami, Chinatown in San Francisco, Greektown in Chicago and Little Italy in New York. On the effect of immigrant clustering on the speed of assimilation and on the welfare of the native population, see Lazear $(1995 \mathrm{a}, \mathrm{b})$.

Assume that in the sending country $S$, social capital $\mathrm{SK}_{\mathrm{s}}$ decreases with the level of migration $\mathrm{M}$ because it reduces the size of the group of people of similar background and values with whom each member of the group can interact. As people migrate, those left behind (family, friends, community, village) experience a loss in social capital (Bliss, p. 76). Emigration results in a 'social capital drain'. The marginal loss in social capital is assumed to increase with the level of migration.

In the receiving country $\mathrm{N}$, social capital $\mathrm{SK}_{\mathrm{n}}$ depends negatively on the migration level. The assumption is that the local population and the immigrants differ significantly in language, customs, values and culture, so that an increase in migration lowers the North's social capital. The marginal loss in social capital is assumed to increase with the level of migration. Our results are not affected if migration has a positive impact on the North's social capital $\mathrm{SK}_{\mathrm{n}}$ at low levels of migration. ${ }^{1 \mathrm{t}} 12$

For the migrants to the North, migration results in a loss of social capital $\left(\mathrm{SK}_{\mathrm{m}}<\mathrm{SK}_{\mathrm{s}}\right)$. Moreover, social capital $\mathrm{SK}_{\mathrm{m}}$ depends positively on both $\mathrm{M}$ and $\mathrm{SK}{ }_{\mathrm{n}}$ and is strictly concave in both variables. Thus, migration has two opposite effects on $\mathrm{SK}_{\mathrm{m}}$. First, $\mathrm{SK}_{\mathrm{m}}$ increases directly with migration because the migrants

\footnotetext{
${ }^{11}$ The negative migration externalities for the non-migrants in the South and for the natives in the North are also discussed in Layard et al. (1992). Note also that the assumption of a negative impact of migration on the North's social capital need not imply a prejudiced attitude towards immigrants. For instance, if immigrants and local residents are alike in all respects except in the language they speak, communication among local residents may become increasingly difficult as the share of immigrants rises.

12 I have assumed that the North's social capital is affected by migration, for instance as described in footnote 11 . One could also model the interaction between the natives of the North and migrants by assuming that the North's social capital only depends on interaction among the North's natives, and that at the same time natives become less hospitable to migrants as their number increases. As long as the lack of hospitality affects the migrants' welfare, the results are unaffected.
} 
benefit from the interaction with a larger number of people from their own group. Second, as migration increases, $\mathrm{SK}_{\mathrm{n}}$ falls, natives of the North become less hospitable, and that leads to a reduction in $\mathrm{SK}_{\mathrm{m}}$.

Even though it rises at first, the migrants' social capital $\mathrm{SK}_{\mathrm{m}}$ eventually falls with migration because the positive effect decreases while the negative effect increases with migration. At that point, under individual utility maximization, migrants who have settled in the North would be expected to resist further immigration since it will lower their utility. In fact, the 1993 Latino National Political Survey found that 65 percent of Hispanics living in the U.S. want limits imposed on further Hispanic immigration (Chavez 1993, Fukuyama 1993). 13

The relationship between social capital and migration described above is given by:

$$
\begin{aligned}
& \mathrm{SK}_{\mathrm{n}}=\mathrm{SK}_{\mathrm{n}}(\mathrm{M}), \mathrm{SK}_{\mathrm{n}}{ }^{\prime}<0, \mathrm{SK}_{\mathrm{n}}{ }^{\prime \prime}<0, \\
& \mathrm{SK}_{\mathrm{s}}=\mathrm{SK}_{\mathrm{s}}(\mathrm{M}), \mathrm{SK}_{\mathrm{s}}{ }^{\prime}<0, \mathrm{SK}_{\mathrm{s}}{ }^{\prime \prime}<0, \\
& \mathrm{SK}_{\mathrm{m}}=\mathrm{SK}_{\mathrm{m}}\left(\mathrm{M}, \mathrm{SK}_{\mathrm{n}}\right), \partial \mathrm{SK}_{\mathrm{m}} / \partial \mathrm{M}>0, \partial \mathrm{SK}_{\mathrm{m}} / \partial \mathrm{SK}_{\mathrm{n}}>0, \\
& \partial^{2} \mathrm{SK}_{\mathrm{m}} / \partial \mathrm{M}^{2}<0, \partial^{2} \mathrm{SK}_{\mathrm{m}} / \partial \mathrm{SK}_{\mathrm{n}}{ }^{2}<0, \\
& \text { and } \mathrm{SK}_{\mathrm{m}}<\mathrm{SK}_{\mathrm{s}} \text { for all M. }
\end{aligned}
$$

\section{Free Migration}

In this section, restrictions on migration -- such as immigration taxes or quotas -- are absent. Assume that migration is costly, with migration cost equal to $\mathrm{C}$. Observed cases of economic migration entail an internal equilibrium where some but not all the population migrates. Hence, assume $0<M<L_{s}$, where $L_{s}$ is the initial (pre-migration) population of the South. Corner solutions are discussed following equation (7).

\subsection{Individual Utility Maximization}

13 Note that these assumptions do not apply to a situation of low population density in the North where there is a 
Assume that migrants maximize their individual utility $\mathrm{U}_{\mathrm{m}}$. In that case, remittances $\mathrm{R}=0$. Migration takes place if $U_{m}>U_{s}$ at $M=0$. Assuming an internal solution (a necessary condition is given in the context of equation (7) below), equilibrium is given by the migration arbitrage condition

(5) $U_{\mathrm{m}}=\mathrm{U}_{\mathrm{s}}$,

$$
\begin{aligned}
& \text { with } U_{m}=X_{m}\left(W_{n}-C, P_{1 n}, P_{2 n}\right)+Z_{n}\left[S K_{m}\left(M, S_{n}(M)\right)\right] \text {, } \\
& \text { and } U_{s}=X_{s}\left(W_{s}, P_{1 s}, P_{2 s}\right)+Z_{s}\left[S_{s}(M)\right] .
\end{aligned}
$$

The equilibrium characterized by equation (5) is not an optimum for the migrants, for the nonemigrants in the South or for the North. This is due to the four types of externalities - described in Section 2 - associated with the effect of migration on social capital. From equations (3)-(5), all groups lose under free migration compared to the no migration situation. Those remaining in the South lose because migrat 


$$
\text { (6) } \begin{aligned}
\mathrm{SP}_{\mathrm{d}} & =\mathrm{P}_{\mathrm{d}}+\mathrm{EX} \\
\mathrm{EX} & =\left[\mathrm{U}_{\mathrm{m}}-\mathrm{U}_{\mathrm{s}}\right) /\left(\partial \mathrm{X}_{\mathrm{m}} / \partial \mathrm{Y}_{\mathrm{m}}\right) \\
& =\left[\mathrm{d} \mathrm{U}_{\mathrm{m}} / \mathrm{dM}\right] /\left(\partial \mathrm{Z}_{\mathrm{m}}{ }^{\prime} \cdot \mathrm{SK}_{\mathrm{m}}{ }^{\prime}\right] /\left(\partial \mathrm{Y}_{\mathrm{m}}\right)+\left[\left(\mathrm{L}_{\mathrm{s}}-\mathrm{M}\right) \cdot \mathrm{dU}_{\mathrm{s}} / \mathrm{dM}_{\mathrm{m}}\right)+\left[\left(\partial \mathrm{X}_{\mathrm{s}} / \partial \mathrm{Y}_{\mathrm{s}}\right)\right. \\
& \left.\mathrm{M}) \cdot \mathrm{Z}_{\mathrm{s}} \cdot \mathrm{SK}_{\mathrm{s}}{ }^{\prime}\right] /\left(\partial \mathrm{X}_{\mathrm{s}} / \partial \mathrm{Y}_{\mathrm{s}}\right)
\end{aligned}
$$

where $\mathrm{SK}_{\mathrm{m}}{ }^{\prime} \equiv \partial \mathrm{SK}_{\mathrm{m}} / \partial \mathrm{M}+\left(\partial \mathrm{SK}_{\mathrm{m}} / \partial \mathrm{SK}_{\mathrm{n}}\right) \cdot \mathrm{SK}_{\mathrm{n}}{ }^{\prime}$.

The second term of EX is negative while the first term might be positive at first but must be negative at the equilibrium (as shown below in the context of equation (7)). Hence, EX might be positive for small values of $M$, but it must be negative at equilibrium. Consequently, $\mathrm{SP}_{\mathrm{d}}$ has been drawn in Figure 1 under the assumption that EX $<0$ for all values of $M$, i.e., $S_{d}<P_{d}$ for all $M$. The upward-sloping curve MC represents the negative externality of migration for the North.

In the absence of an immigration policy by the North, the free migration equilibrium is at point $\mathrm{C}$ where $P_{d}=0$ or $U_{m}=U_{s}$. The social optimum for the South is at the lower migration level shown by point $\mathrm{B}$ where $\mathrm{SP}_{\mathrm{d}}=0$, with a net social gain from migration equal to triangle $\mathrm{ABO}$. The net welfare effect of migration for the South is (triangle $A B O$ - triangle $B C F$ ) $<0$ (since $U_{s}$ and $U_{m}=U_{s}$ fall with migration). The loss to the North is the area under the MC curve between points $\mathrm{O}$ and $\mathrm{C}$.

In the presence of social capital, Bhagwati's argument (1991) on the optimality of free migration does not hold. Equilibrium in the absence of internalization of migration externalities is at point $\mathrm{C}$, but the optimum for the South is at point $\mathrm{B}$, the optimum for the North is at point $\mathrm{O}$ (no migration), and the global optimum is at point $\mathrm{G}$ where $\mathrm{SP}_{\mathrm{d}}=\mathrm{MC} .14$

To examine the impact on migration and welfare of a reduction in migration costs and of imposing

14. A similar result is obtained by Francois (1994) who shows that migration can reduce global welfare in a model with Ethier-type trade in intermediates and spillover effects associated with international scale economies. Baldwin and Venables (1994), who examine the transition in Central and Eastern Europe (CEE), show that free migration (emigration restrictions) may result in low (high) levels of capital, skilled labor and per capita income in the long run. They do not examine the effect of emigration restrictions on the joint income of emigrants and non-emigrants of the CEE or on the income of natives in the West. 
a tariff, equation (5) is differentiated totally to obtain

(7) $\mathrm{dM}=\left\{\left(\partial \mathrm{X}_{\mathrm{m}} / \partial \mathrm{Y}_{\mathrm{m}}\right) \cdot \mathrm{d}\left(\mathrm{W}_{\mathrm{n}}-\mathrm{C}\right)+\left(\partial \mathrm{X}_{\mathrm{m}} / \partial \mathrm{P}_{1 \mathrm{n}}\right) \cdot \mathrm{dP}_{1 \mathrm{n}}+\left(\partial \mathrm{X}_{\mathrm{m}} / \partial \mathrm{P}_{2 \mathrm{n}}\right) \cdot \mathrm{dP}_{2 \mathrm{n}}-\right.$

$\left.\left[\left(\partial \mathrm{X}_{\mathrm{s}} / \partial \mathrm{Y}_{\mathrm{s}}\right) \cdot \mathrm{dW}_{\mathrm{s}}+\left(\partial \mathrm{X}_{\mathrm{s}} / \partial \mathrm{P}_{\mathrm{Is}}\right) \cdot \mathrm{dP}_{1 \mathrm{~s}}+\left(\partial \mathrm{X}_{\mathrm{s}} / \partial \mathrm{P}_{2 \mathrm{~s}}\right) \cdot \mathrm{dP}_{2 \mathrm{~s}}\right]\right\} / \mathrm{A}$

where $A \equiv Z_{s}{ }^{\prime} \cdot S_{s}{ }^{\prime}-Z_{m}{ }^{\prime} \cdot S_{m}{ }^{\prime}$.

That $A>0$ is a necessary condition for an internal migration solution is shown as follows. $U_{m}>$ $\mathrm{U}_{s}$ at $\mathrm{M}=0$ if migration takes place. As migration increases, $\mathrm{U}_{\mathrm{s}}$ falls. For an internal equilibrium, $\mathrm{U}_{\mathrm{m}}$ must be equal to $U_{s}$. Thus, $U_{m}$ must fall faster than $U_{s}$. And since factor prices are not affected by migration (as long as there is no specialization), it follows that the fall in $\mathrm{U}_{\mathrm{m}}$ due to the fall in $\mathrm{SK}_{\mathrm{m}}$ must be larger than the fall in $\mathrm{U}_{\mathrm{s}}$ due to the fall in $\mathrm{SK}_{\mathrm{s}}$. This is identical to the condition that $\mathrm{A}>0 .{ }^{15}$

What about corner solutions? As noted above, $\mathrm{A}>0$ is a necessary condition for an internal equilibrium with diversified output. However, even if $A \leq 0$, an internal migration solution obtains because migration results in specialization. Assume $\mathrm{A} \leq 0$. Then, at existing wages, migration does not lead to equalization of $U_{s}$ and $U_{m}$. As migration proceeds, output of good 2 (the labor-intensive exportable) falls and output of good 1 (the capital-intensive importable) increases, with a decrease in trade. When the capital-labor ratio in the South equals that in the world, trade stops. With further migration, the South becomes abundant in capital, exporting good 1 and importing good 2. At some point, endowments are no longer in the cone of diversification and the South stops producing good 2. As migration proceeds, wages in the South rise. Given that labor's marginal productivity tends to infinity as the labor-capital ratio tends to zero (see equation (1)), $U_{s}$ reaches equality with $U_{m}$ before the entire labor force of the South has emigrated. In that case, $U_{s}\left(=U_{m}\right)$ may be higher or lower under free migration than in the absence of migration. In what follows, I assume output in the South remains diversified, and $\mathrm{A}>0$.

\footnotetext{
${ }^{15}$ Assume $A>0$ at the lowest-migration equilibrium, with $M=M_{0} . d A / d M=\left[Z_{s}{ }^{\prime} . S K{ }_{s}{ }^{\prime \prime}+Z_{s}{ }^{\prime \prime} .\left(S K K_{s}{ }^{\prime}\right)^{2}\right]-$ $\left[Z_{m}{ }^{\prime} \cdot S K_{m}{ }^{\prime \prime}+Z_{m}{ }^{\prime \prime} \cdot\left(S K_{m}{ }^{\prime}\right)^{2}\right] \geq 0$ for $M>M_{0}$ is a sufficient condition for uniqueness. $d A / d M \geq O$ for $M>M_{0}$ means that A remains positive as $M$ increases. In other words, the slope of $U_{m}$ remains larger (in absolute value) than the slope of $\mathrm{U}_{\mathrm{s}}$, and the equilibrium is unique. If $\mathrm{dA} / \mathrm{dM}<0$ for $\mathrm{M}>\mathrm{M}_{0}$, there may be one or more equilibria.
} 
What is the effect of a fall in migration costs? From equation (7),

(8) $\mathrm{dM} / \mathrm{dC}=-\left(\partial \mathrm{X}_{\mathrm{m}} / \partial \mathrm{Y}_{\mathrm{m}}\right) / \mathrm{A}<0$

A fall in migration costs results in immiserization for all groups (except capital whose income remains unchanged). Migration increases and $\mathrm{SK}_{\mathrm{s}}$ and $\mathrm{U}_{\mathrm{s}}$ fall. Since in equilibrium, $\mathrm{U}_{\mathrm{m}}=\mathrm{U}_{\mathrm{s}}, \mathrm{U}_{\mathrm{m}}$ falls as well. And $\mathrm{U}_{\mathrm{n}}$ falls since $\mathrm{SK}_{\mathrm{n}}{ }^{\prime}<0$. Note that if the increase in migration is large enough, the South could become capital abundant in the new equilibrium and export the capital-intensive good.

What about the impact of imposing a tariff $\mathrm{T}$ on the imports of good 1 in the South? Then, $\mathrm{P}_{1 \mathrm{~s}}=\mathrm{P}_{1}{ }^{*}$ + T. From equation $(7)$, we have

(9) $\mathrm{dM} / \mathrm{dT}=-\left[\left(\partial \mathrm{X}_{\mathrm{s}} / \partial \mathrm{Y}_{\mathrm{s}}\right) \cdot\left(\partial \mathrm{W}_{\mathrm{s}} / \partial \mathrm{T}\right)+\partial \mathrm{X}_{\mathrm{s}} / \partial \mathrm{P}_{\mathrm{is}}\right] / \mathrm{A}>0$

since $\partial \mathrm{W}_{s} / \partial \mathrm{T}$ and $\partial \mathrm{X}_{\mathrm{s}} / \partial \mathrm{P}_{\mathrm{Is}}$ are negative. Thus, imposing a tariff in the South leads to an increase in migration. $U_{s}$ falls because of labor's real income loss and because $S K_{s}$ falls. $U_{m}=U_{s}$ falls as well, and $U_{n}$ falls since $\mathrm{SK}_{\mathrm{n}}{ }^{\prime}<0$. Capital's real income rises in the South (magnification effect) and remains unchanged in the North. The South as a whole loses because of the trade distortion and the loss in social capital. The North loses because of the loss of social capital.

A similar result obtains if the North imposes a tariff on its labor-intensive imports. The real wage in the North rises, resulting in an increase in migration; thus, $U_{s}$ falls (as social capital falls) and so does $U_{m}=$ $\mathrm{U}_{s}$. The effect on labor in the North is ambiguous because the real wage rises while social capital falls. Capital's real income in the North falls. The North as a whole loses because of the trade distortion and the loss of social capital. The South loses as real factor income is unchanged but social capital falls. The above results are given in Table 1 and can be summarized by

Proposition 1. Under individual utility maximization

1) all labor groups (natives of the North and South and migrants) are worse off under free migration than with total restriction on migration, and capital is not affected;

2) natives in the North and South and migrants, and the North and South as a whole, lose from imposing a 
tariff in the South, while capital's income rises in the South and is unchanged in the North; migrants and natives in the South, as well as capital in the North, and the North and South as a whole, lose from a tariff in the North, while capital in the South is unaffected and the impact on labor in the North is ambiguous;

3) all labor groups lose from a decrease in migration costs, and capital's real income is unchanged.

\subsection{Collective Welfare Maximization}

Several studies indicate that migration is a collective rather than an individual decision (e.g., Stark 1991). The decision-making group may be the household, the extended family or the community. Assume that the group maximizing welfare is the South's population or labor force.16 Then, the effect of emigration on the social capital of the South's non-emigrants $\left(\mathrm{SK}_{\mathrm{s}}\right)$ and emigrants $\left(\mathrm{SK}_{\mathrm{m}}\right)$ is completely internalized. ${ }^{17}$

Defining the welfare of labor in the South $\mathrm{NW}_{s}$ as the sum of the utilities of the emigrants and nonemigrants of the South, the problem is to determine the levels of migration $M$ and of remittances per migrant $\mathrm{R}$ which maximize

$$
\begin{aligned}
\mathrm{NW}_{\mathrm{s}}= & \mathrm{V}_{\mathrm{s}}+\mathrm{V}_{\mathrm{m}}=\left(\mathrm{L}_{\mathrm{s}}-\mathrm{M}\right) \cdot \mathrm{U}_{\mathrm{s}}+\mathrm{M} \cdot \mathrm{U}_{\mathrm{m}} \\
= & \left(\mathrm{L}_{\mathrm{s}}-\mathrm{M}\right) \cdot\left\{\mathrm{X}_{\mathrm{s}}\left(\mathrm{W}_{\mathrm{s}}+\mathrm{R} \cdot \mathrm{M} /\left(\mathrm{L}_{\mathrm{s}}-\mathrm{M}\right), \mathrm{P}_{\mathrm{ls}}, \mathrm{P}_{2 \mathrm{~s}}\right)+\mathrm{Z}_{\mathrm{s}}\left[\mathrm{SK}_{\mathrm{s}}(\mathrm{M})\right]\right\} \\
& +\mathrm{M} \cdot\left\{\mathrm{X}_{\mathrm{m}}\left(\mathrm{W}_{\mathrm{n}}-\mathrm{C}-\mathrm{R}, \mathrm{P}_{\mathrm{In}}, \mathrm{P}_{2 \mathrm{n}}\right)+\mathrm{Z}_{\mathrm{m}}\left[\mathrm{SK}_{\mathrm{m}}\left(\mathrm{M}, \mathrm{SK}_{\mathrm{n}}(\mathrm{M})\right)\right]\right\}
\end{aligned}
$$

where $V_{s}\left(V_{m}\right)$ is the welfare of the non-emigrants (emigrants) of the South, and remittances are evenly distributed among the non-emigrants, each of whom gets R.M $/\left(L_{s}-M\right)$. Setting $\partial N W_{s} / \partial R=0$, we have

(11) $\partial \mathrm{X}_{\mathrm{s}} / \partial \mathrm{Y}_{\mathrm{s}}=\partial \mathrm{X}_{\mathrm{m}} / \partial \mathrm{Y}_{\mathrm{m}}$

Hence, in order to maximize $\mathrm{NW}_{\mathrm{s}}$, emigrants remit to the point where the marginal utilities of income

\footnotetext{
$16 \mathrm{I}$ assume that as a fixed factor, capital is not involved in the migration decision, that it does not support migration and receives no remittances from migrants.

${ }^{17}$ Experimental evidence on internalization of other people's welfare is provided in Andreoni (1995) and Andreoni and Miller (1993). These studies find that partial cooperation takes place in public-goods experiments among strangers even though free riding is the dominant strategy. Chirinko (1990) provides a theoretical analysis of the role of social capital in the private provision of public goods.
} 
for the migrants living in the North and for the non-emigrants in the South are equalized. Given that prices are the same in the North and South under free trade, equation (11) implies $Y_{s}=Y_{m}$. Setting $\partial N W_{s} / \partial M=$ 0 and making use of equations $(10),(11)$, and of $Y_{s}=Y_{m}$, we have

$$
\text { (12) } \begin{aligned}
& \mathrm{R}=\left[\left(\mathrm{L}_{\mathrm{s}}-\mathrm{M}\right) / \mathrm{L}_{\mathrm{s}}\right] \cdot\left(\mathrm{W}_{\mathrm{n}}-\mathrm{C}-\mathrm{W}_{\mathrm{s}}\right)>0 \\
& \mathrm{~W}_{\mathrm{n}}-\mathrm{C}-\mathrm{W}_{\mathrm{s}}=\left(\mathrm{U}_{\mathrm{s}}-\mathrm{U}_{\mathrm{m}}\right) /\left(\partial \mathrm{X}_{\mathrm{s}} / \partial \mathrm{Y}_{\mathrm{s}}\right)-\mathrm{EX}
\end{aligned}
$$

where EX is defined in equation (6).

Equation (12) says that remittances are such as to equate $Y_{s}$ and $Y_{m}$, and migration is such as to equate the income gain from migration $\left(\mathrm{W}_{\mathrm{n}}-\mathrm{C}-\mathrm{W}_{\mathrm{s}}\right)$ to the sum of the loss of individual utility from migration $\left(\mathrm{U}_{\mathrm{s}}\right.$ $\left.-\mathrm{U}_{\mathrm{m}}\right) /\left(\partial \mathrm{X}_{\mathrm{s}} / \partial \mathrm{Y}_{\mathrm{s}}\right)$ and the loss (-EX) due to the fall in the social capital of the South's emigrants and nonemigrants.

The South's welfare labor $\mathrm{NW}_{\mathrm{s}}$ is higher in this case than in the absence of migration or in the case of free migration under individual utility maximization since all externalities affecting $\mathrm{NW}_{\mathrm{s}}$ are internalized. There are two opposite effects on migration compared to the case of individual utility maximization (point $\mathrm{C}$ in Figure 1). First, migration falls with internalization of the effects on $\mathrm{SK}_{\mathrm{s}}$ and $\mathrm{SK}_{\mathrm{m}}$ (point $\mathrm{B}$ in Figure 1). Second, recall that the social gain of migration for the South $\mathrm{SP}_{\mathrm{d}}$ was obtained for $\mathrm{R}=0$. However, now that remittances are given by equation (12), the social gain from migration at point $B$ is positive. Hence, the optimal migration level is to the right of point $B$. Whether welfare in the North is higher or lower depends on whether the optimal migration level is smaller or larger, respectively, than the one under individual utility maximization (point C). Thus, Bhagwati's point on the optimality of free migration holds for the South in this case, though not for the North or the North and South taken as a whole (capital's income is not affected).

What occurs with a fall in migration costs? Since all migration externalities are internalized by the South, $\mathrm{NW}_{\mathrm{s}}$ increases when $\mathrm{C}$ falls. The effect on migration and remittances can be derived from equation (12). At the initial values of $\mathrm{M}$ and $\mathrm{R}, \partial \mathrm{NW} / \mathrm{s} / \partial \mathrm{M}$ (since $\mathrm{Y}_{\mathrm{m}}$ is higher) and $\partial \mathrm{NW}_{\mathrm{s}} / \partial \mathrm{R}>0$ (since $\mathrm{Y}_{\mathrm{m}}>$ $\mathrm{Y}_{\mathrm{s}}$ and $\left.\partial \mathrm{X}_{\mathrm{m}} / \partial \mathrm{Y}_{\mathrm{m}}<\partial \mathrm{X}_{\mathrm{s}} / \partial \mathrm{Y}_{\mathrm{s}}\right)$. Thus, both migration and remittances increase. Given the increase in 
migration, $\mathrm{U}_{\mathrm{n}}$ falls. Capital income is not affected.

If the South imposes an import tariff, capital gains, the wage rate $W_{s}$ falls, migration increases and $U_{n}$ falls. Since the marginal utility of income for non-emigrants rises above that of emigrants, the level of remittances $\mathrm{R}$ increases as well (equation (12)). The South internalizes all the migration externalities but its labor welfare $\mathrm{NW}_{\mathrm{s}}$ falls because of the trade distortion. The North's real income is not affected but it loses because of the loss in social capital.

If the North imposes a tariff on its labor-intensive imports, capital in the North loses, $\mathrm{W}_{\mathrm{n}}$ rises, migration and remittances increase, the North loses (from the trade distortion and the loss in social capital) and the South gains. The South gains at the initial level of migration and remittances because migrants now obtain a higher wage in the North, and it gains by adjusting the levels of migration and remittances optimally. Though the North as a whole loses, the impact on labor in the North is ambiguous: it gains from the higher wage and loses from the decline in social capital.

The above results are presented in Table 1 and can be summarized by

Proposition 2. Under collective welfare $\left(\mathrm{NW}_{s}\right)$ maximization in the South,

1) $N W_{s}$ is higher and welfare for natives of the North $U_{n}$ is lower under free migration than with total restriction on migration, while capital is unaffected;

2) $N W_{s}$ is higher than under individual utility maximization, but the effect on $U_{n}$ is ambiguous;

3) a tariff by the South lowers $\mathrm{NW}_{s}$ and $\mathrm{U}_{n}$; capital in the South gains and that in the North is unaffected;

4) $\mathrm{NW}_{\mathrm{s}}$ increases and $U_{\mathrm{n}}$ falls with a fall in migration costs or with a tariff by the North; and though the North as a whole loses from the tariff, the impact on the North's labor is ambiguous.

\section{Optimal Immigration Restriction}

Following the 1973 oil shock and the subsequent recession and rise in unemployment in Europe, policy changed from one of encouraging immigration to what Zimmerman (1995) has called a "'Fortress Europe' 
immigration policy": He describes many Europeans as feeling that they belong to a club and that immigrants should pay an entry fee for access to the club and its valuable resources (i.e., high wages). He argues that such an instrument could be used to control immigration flows. Similarly, Becker (1987) has proposed auctioning U.S. immigrant visas. And immigration quotas have been reduced by $20 \%$ in the last two years in Australia and further cuts are being considered. Bhagwati and Srinivasan (1983) have also examined the effect of immigration quotas and taxes. The impact of such a policy is examined in this section.

Assume that the North sets an immigration tax $T_{n}$ (or, equivalently, that it sets a quota which is auctioned to the immigrants). There are many ways to collect the tax, including fees to obtain immigration papers and payment of lower wages in a segmented labor market. Authorities in the North choose $T_{n}$ to maximize the North's welfare, $V_{n}$, subject to a constraint. If migrants maximize individual utility, the constraint is the migration arbitrage condition $U_{m}=U_{s}$ with $R=0$. If migration is part of a collective welfare maximization process, the constraint is the maximization of welfare $\mathrm{NW}_{\mathrm{s}}$ by the South. Assume that immigration tax revenues $T_{n} \cdot M$ are distributed uniformly among the $L_{n}$ local residents in the North. Then, per capita tax revenue is $T_{n} \cdot M / L_{n}$. Since $L_{n}$ is given, maximizing $V_{n}=L_{n} \cdot U_{n}$ is equivalent to maximizing $U_{n}$.

\subsection{Individual Utility Maximization}

$\mathrm{U}_{\mathrm{n}}$ is given by

(13) $U_{n}=X_{n}\left(W_{n}+T_{n} \cdot M / L_{n}, P_{l n}, P_{2 n}\right)+Z_{n}\left[S_{n}(M)\right]$.

The problem for the North is to select an immigration tax $T_{n}$ in order to maximize $U_{n}$ subject to $U_{m}$ $=\mathrm{U}_{\mathrm{s}}$ and $\mathrm{R}=0$. Then, $\mathrm{U}_{\mathrm{m}}$ [equation (5)] becomes

(14) $U_{m}=X_{m}\left(W_{n}-C-T_{n}, P_{1 m}, P_{2 n}\right)+Z_{m}\left[S K_{m}\left(M, S_{n}(M)\right)\right]$,

and $\mathrm{dM}$ [equation (7)] becomes

(15) $\mathrm{dM}=\left\{\left(\partial \mathrm{X}_{\mathrm{m}} / \partial \mathrm{Y}_{\mathrm{m}}\right) \cdot \mathrm{d}\left(\mathrm{W}_{\mathrm{n}}-\mathrm{T}_{\mathrm{n}}-\mathrm{C}\right)+\left(\partial \mathrm{X}_{\mathrm{m}} / \partial \mathrm{P}_{1 \mathrm{n}}\right) \cdot \mathrm{dP}_{\mathrm{ln}}+\left(\partial \mathrm{X}_{\mathrm{m}} / \partial \mathrm{P}_{2 \mathrm{n}}\right) \cdot \mathrm{dP}_{2 \mathrm{n}}\right.$ 


$$
\left.-\left[\left(\partial \mathrm{X}_{\mathrm{s}} / \partial \mathrm{Y}_{\mathrm{s}}\right) \cdot \mathrm{dW}_{\mathrm{s}}+\left(\partial \mathrm{X}_{\mathrm{s}} / \partial \mathrm{P}_{1 \mathrm{~s}}\right) \cdot \mathrm{dP}_{1 \mathrm{~s}}+\left(\partial \mathrm{X}_{\mathrm{s}} / \partial \mathrm{P}_{2 \mathrm{~s}}\right) \cdot \mathrm{dP}_{2 \mathrm{~s}}\right]\right\} / \mathrm{A}
$$

with $\mathrm{A}$ defined in equation (7).

Maximizing $U_{n}$ with respect to $T_{n}$ subject to equation (15), we obtain

(16) $T_{n}=A \cdot M /\left(\partial X_{m} / \partial Y_{m}\right)-Z_{n}^{\prime} \cdot S K_{n}^{\prime} \cdot L_{n} /\left(\partial X_{n} / \partial Y_{n}\right)>0$

The North as a whole is better off in the optimal immigration tax case than in the case of free migration $\left(T_{n}=0\right)$ and of no migration $(M=0)$ because it disposes of an additional instrument to maximize its welfare $V_{n}$. How does welfare in the South $U_{s}=U_{m}$ compare under these three alternative scenarios? Factor prices (and capital and labor's real income) in the South are unaffected by the immigration tax $T_{n}$. Thus, the effect on $U_{s}$ (and on $U_{m}=U_{s}$ ) depends entirely on the impact on $\mathrm{SK}_{s}$. From equation (15), migration falls - and hence $\mathrm{SK}_{\mathrm{s}}$ increases - with an increase in $\mathrm{T}_{\mathrm{n}}$. Thus, the South's welfare is lowest under free migration, it is higher in the case of an optimal immigration tax, and it is highest under total restriction on migration.

An immigration tax reduces migration and thus reduces the externalities migration causes. This raises the South's pre-tax welfare for migrants and non-migrants. A more unusual result is that the welfare increase associated with the higher level of social capital dominates the income loss due to the tax, so that after-tax welfare rises as well. ${ }^{18}$

The results are illustrated in Figure 1. Maximum welfare for the North under an immigration tax is obtained where $\mathrm{MC}=\mathrm{MR}$. Then, equilibrium is at point $\mathrm{E}$, migration equals $\mathrm{OH}$, and $\mathrm{T}_{\mathrm{n}}=\mathrm{EH}$. Welfare for the South is higher than in the absence of the tax because $U_{s}\left(=U_{m}\right)$ is higher at the lower migration level (point $\mathrm{H}$ ). The welfare increase for the South under the tax is equal to triangle CFB minus triangle $\mathrm{HBJ}$ minus the tax payments $\mathrm{OHET}_{\mathrm{n}}$. Welfare for the South is lower under the tax than in the absence of migration (the gain AJHO is smaller than the tax payment $\mathrm{OHET}_{n}$ ). The gain from migration for the North is the tax revenue

\footnotetext{
${ }^{18} \mathrm{~A}$ similar result is found for congested common property resources when congestion reaches a critical level (Schiff, $1992 b)$.
} 
$T_{n} \cdot M$ or area $\mathrm{OHET}_{n}$ minus the area under the MC curve between $\mathrm{O}$ and $H$. This gain is larger than the gain (equal to zero) in the absence of migration and larger than the gain under free migration (a loss equal to the area under the $\mathrm{MC}$ curve between points $\mathrm{O}$ and $\mathrm{C}$ ).

A tariff in the South results in a decrease in $\mathrm{U}_{\mathrm{s}}$. The wage rate in the South, $\mathrm{W}_{\mathrm{s}}$, falls and migration increases (equation (15)). Labor loses because of the lower wage and the lower level of social capital. Capital gains but the South as a whole loses due to the trade distortion and loss in social capital. Since $U_{s}=U_{m}, U_{m}$ falls as well. On the other hand, $U_{n}$ increases because of the increase in the South's migration demand.

A fall in the migration cost $\mathrm{C}$ results in an increase in migration (equation (15)), $\mathrm{SK}_{\mathrm{s}}$ falls, and $\mathrm{U}_{s}$ and $\mathrm{U}_{\mathrm{m}}=\mathrm{U}_{\mathrm{s}}$ fall. The North gains because of the increased migration demand. Note also that migrants and nonmigrants in the South lose from a tariff in the North, while the impact on the North as a whole is ambiguous (it loses from the trade distortion but gains from the increase in the South's migration demand). On the other

hand, labor in the North gains both from the higher wage and from the increase in the South's migration demand.

Note that under free migration, any change in policy or costs in the South which results in an increase in migration demand implies a loss to the North. Under the optimal immigration tax, the opposite is true. Any increase in migration demand due to a change in the South results in a gain for the North. In this case, the North holds monopoly power over a scarce resource, namely access to the North's high-wage labor market. The larger the demand for the monopolist's resource, the better off it is.

\section{Illegal Migration}

Assume that a fraction $\beta<1$ of migrants pays the immigration tax, while a fraction $1-\beta$ does not, and --for simplicity--that migrants only decide whether to migrate legally or not upon arrival to the North. The effective migration demand from which the North can extract an immigration tax is lower in this case than in the absence of illegal migration, the optimal immigration tax $T_{n}$ is lower as well, and the number of migrants 
is larger. Those remaining in the South lose because social capital $\mathrm{SK}_{\mathrm{s}}$ is lower, and on average migrants lose as well since $U_{m}=U_{s}$, where $U_{m}$ is an average of the utility of legal $\left(U_{L}\right)$ and illegal $\left(U_{n}\right)$ migrants. Legal migrants' utility $U_{L}$ is lower than $U_{m}$, and since $U_{m}$ falls, so does $U_{L}$. Illegal migrants' utility $U_{I L}$ is higher than $U_{m}$ but the impact on $U_{I L}$ is ambiguous since illegal migrants gain from evading the immigration tax but lose from a lower level of social capital $\mathrm{SK}_{\mathrm{m}}$ associated with the larger number of migrants. The North loses because its revenue from the immigration tax is lower and because social capital $\mathrm{SK}_{\mathrm{n}}$ is lower.

The above results are given in Table 1 and can be summarized by

Proposition 3. With individual utility maximization and an optimal immigration tax,

1) the North is better off than with free migration $\left(T_{n}=0\right)$ or with no migration $(M=0)$;

2) the Southern emigrants and non-emigrants are better off than under free migration but worse off than under total restriction on migration;

3) a tariff in the South or a decrease in migration costs lowers welfare for migrants and non-migrants in the South and raises welfare in the North (while capital in the South loses with a tariff); a tariff in the North lowers welfare for migrants and non-migrants in the South, and while labor in the North gains, the effect on the North as a whole is ambiguous; and

4) all labor groups lose under illegal immigration, except for the illegal immigrants for whom the welfare impact is ambiguous.

\subsection{Collective Welfare Maximization}

In this case, the North maximizes $U_{n}$ [see equation (13)] subject to the South maximizing $N_{s} . N_{s}$ defined in equation (10) now becomes:

$$
\text { (17) } \begin{aligned}
\mathrm{NW}_{\mathrm{s}}= & \left(\mathrm{L}_{\mathrm{s}}-\mathrm{M}\right) \cdot\left\{\mathrm{X}_{\mathrm{s}}\left[\mathrm{W}_{\mathrm{s}}+\mathrm{R} \cdot \mathrm{M} /\left(\mathrm{L}_{\mathrm{s}}-\mathrm{M}\right), \mathrm{P}_{\mathrm{ss}}, \mathrm{P}_{2 \mathrm{~s}}\right]+\mathrm{Z}_{\mathrm{s}}\left[\mathrm{SK}_{\mathrm{s}}(\mathrm{M})\right]\right\} \\
& +\mathrm{M} \cdot\left\{\mathrm{X}_{\mathrm{m}}\left(\mathrm{W}_{\mathrm{n}}-\mathrm{C}-\mathrm{T}_{\mathrm{n}}-\mathrm{R}, \mathrm{P}_{1 \mathrm{~m}}, \mathrm{P}_{2 \mathrm{~m}}\right)+\mathrm{Z}_{\mathrm{m}}\left[\mathrm{SK}_{\mathrm{m}}\left(\mathrm{M}, \mathrm{SK}_{\mathrm{n}}(\mathrm{M})\right]\right\} .\right.
\end{aligned}
$$


I assume that the South maximizes $\mathrm{NW}_{\mathrm{s}}$ taking $\mathrm{T}_{\mathrm{n}}$ as exogenously determined. ${ }^{19}$ Its control variables are the level of migration and of remittances. As in the case of free migration, the optimal level of remittances is such as to equate the marginal utility of income of emigrants and non-emigrants (equation (11)). The results are shown in Figure 1. Assume for illustrative purposes that the curve $\mathrm{SP}_{d}$ represents the South's gains from - and its maximum willingness to pay for - migration under collective welfare maximization. Given $\mathrm{SP}_{d}$, the North's optimum is where $\mathrm{MC}=\mathrm{MR}^{\prime}$. Equilibrium is at point $\mathrm{E}^{\prime}$, migration is $\mathrm{OH}^{\prime}$ and the optimal tax $\mathrm{Tn}^{\prime}$ $=E^{\prime} H^{\prime}$. The South is worse off with the tax than under free migration, with welfare in the South falling from $A B O$ to $\mathrm{AE}^{\prime} \mathrm{T}_{n}{ }^{\prime}$. The welfare gain for the North is $\mathrm{T}_{n}{ }^{\prime} \mathrm{E}^{\prime} \mathrm{H}^{\prime} \mathrm{O}$ minus the area under the $M C$ curve between points $\mathrm{O}$ and $\mathrm{H}^{\prime}$. The equilibrium at $\mathrm{E}^{\prime}$ does not maximize global welfare. That is obtained at point $\mathrm{G}$ which is reached if the North imposes a tax $T_{g}$. Then, $M C=S P_{d}$ and all migration externalities are internalized. However, as the North is concerned with its own welfare rather than with global welfare, it exploits its monopoly power by levying a tax $\mathrm{T}_{\mathrm{n}}{ }^{\prime}>\mathrm{T}_{\mathrm{g}}$ (or by auctioning a quota equal to $\mathrm{OH}^{\prime}<\mathrm{OL}$ ).

Bhagwati and Srinivasan (1983) find that an immigration tax raises welfare in the North and lowers it in the South as well as globally. Our results under internalization of migration externalities are close to theirs in this case, though not the effect on global welfare. The impact on global welfare is positive for a tax up to $T_{g}$ but is ambiguous for a higher tax such as $T_{n}$.

Note that in the optimal migration tax case, as in the case of free migration, the effect on migration of switching from individual utility maximization to collective welfare maximization is ambiguous. Migration falls with the internalization of the migration externalities, but it increases with the switch from zero to positive remittances. $\mathrm{NW}_{\mathrm{s}}$ is higher under collective welfare maximization since all externalities are internalized while the effect on the North's welfare is ambiguous (given the ambiguous effect on migration demand).

${ }^{19}$ The South might want to use the level of migration as a strategic variable since a reduction in migration implies a lower immigration tax. As mentioned earlier, I assume that the South does not restrict migration. These strategic issues will be examined in future work (see Section 5). 
A fall in migration costs generates an increase in $\mathrm{NW}_{\mathrm{s}}$. The South gains from the lower migration cost for given levels of migration and remittances, and it gains by changing the level of migration and remittances optimally. The North gains as well since demand for migration increases with the fall in migration costs. A tariff by the South results in a gain for capital in the South, a decrease in $\mathrm{W}_{\mathrm{s}}$, more migration, higher remittances, a loss for the South, a higher immigration tax and a gain for the North. A tariff by the North results in a gain for the South and has an ambiguous impact on the North as a whole, though labor in the North gains (and capital loses). The North loses and the South gains under illegal migration.

The above results are presented in Table 1 and can be summarized by

Proposition 4 Under collective welfare maximization by the South and an optimal immigration tax, 1) the South's national welfare is higher than under individual utility maximization while the effect on the North's welfare is ambiguous;

2) both the South and the North gain from a decrease in migration costs;

3) the South loses and the North gains from a tariff in the South; the South gains from a tariff in the North, and while labor in the North gains, the effect on the North as a whole is ambiguous; and 4) the North loses and the South gains in the case of illegal migration.

\section{Concluding Comments}

The movement of people differs from the movement of goods and services because people create attachments. They tend to feel closer to those with whom they share social capital - including customs, values, language, history and culture - and they interact with them at lower cost. Consequently, migration generates externalities.

Two results hold irrespective of the degree of internalization of the migration externalities: the South gains from liberalizing its trade, and the North gains from imposing an immigration tax. The policy implications are clear: the South should liberalize trade while the North should impose an immigration tax. 
The latter has been proposed by Zimmerman (1995) for the EU. Becker (1987) has proposed a similar solution for the U.S. Note that our analysis does not suggest that immigration should be banned, which is clearly sub-optimal, but rather argues for some form of control on migration.

Note also that these policy recommendations improve the distribution of income in the North and South by improving the welfare of labor relative to that of capital. Trade liberalization in the South results in higher wages (and social capital) and lower returns to capital. An immigration tax in the North has no impact on capital but labor gains from collecting the tax (and from higher social capital).

As found by Wellisch and Walz (1998, this Review), though free trade is optimal for the North under free migration, free migration is not optimal under free trade. The optimum is to control migration. If this involves an immigration tax (or, equivalently, auctioning immigration visas), then the optimum tariff is positive. Otherwise, the optimum tariff is zero.

Note that the results obtained here have been derived under special assumptions. We have ruled out terms-of-trade and scale-related effects and effects of migration on real incomes (but see the discussion of corner solutions in Section 3.1). It is likely that a combination of these effects might weaken the qualitative results identified here. Even so, this paper has argued that the concept of social capital reflects important aspects of the real world, and has shown that incorporating it in the analysis can radically affect the standard results on migration and trade. 20

The analysis presented here can be extended in several directions. First, one might consider dynamic aspects, including the possibility of return migration, of migrants acquiring social capital of the Northern type over time, and of a Northern policy of temporary (rotating) migration.

Second, one might want to consider emigration policy as well as immigration policy. For instance, Bhagwati (1976) and Djajic and Milbourne (1988) examined the impact of emigration taxes, while

20 Social capital was modeled as an argument of the utility function. Similar results are obtained if social capital is modeled as an argument of the production function. A major difference is that internalization of migration externalities is less likely to occur in the latter case. Then, the South also gains under the North's optimal immigration tax. 
Lucas (1987) examined emigration quotas in the context of emigration to South Africa. In the case of both emigration taxes in the South and immigration taxes in the North, optimal tax levels would be determined strategically.

Third, emigration might originate in more than one sending country. For instance, most immigrants to the EU come from various North African and Sub-Sahara African countries as well as from Eastern Europe and the Near East. Similarly, immigrants to the U.S. and Canada originate in various Latin American, Caribbean and Asian countries. In that case, strategic interaction might also take place between the various sending countries. ${ }^{21}$

\footnotetext{
${ }^{21}$ This has been examined for commodity exports in Panagariya and Schiff (1994).
} 


\section{REFERENCES}

James Andreoni. 1995. "Cooperation in Public-Goods Experiments: Kindness or Confusion?"AER 85(4): 891-904.

and J.H. Miller. 1993. "Rational Cooperation in the Finitely Repeated Prisoner's Dilemma: Experimental Evidence". Economic Journal 103 (May): 570-85.

Richard Baldwin and Anthony J. Venables. 1994. "International Migration, Capital Mobility and Transitional Dynamics". Economica 61:285 - 300 .

Edward J. Balistreri. 1997. "The performance of the Heckscher-Ohlin-Vanek model in predicting endogenous policy forces at the individual level". Canadian Journal of Economics 30 (1): 1-17.

Robert Barro and X. Sala-i-Martin. 1992. "Regional Growth and Migration: A Japan-United States Comparison". Journal of the International and Japanese Economies 6: 312-46. 1995. Economic Growth. New York: McGraw-Hill.

Gary S. Becker. 1987. "Why Not Let Immigrants Pay for Speedy Entry?" Business Week, March 2.

. 1996. "Preferences and Values", Chapter 1 in his The Making of Preferences and Values. Harvard University Press: Cambridge, Mass.

Jagdish Bhagwati.1972. "The United States in the Nixon era: The end of innocence". Daedalus. 1976. (ed.) The Brain Drain and Taxation: Theory and Empirical Analysis. Amsterdam: North Holland. 1979. "International factor movements and national advantage: The 9th Ramaswami lecture". Indian Economic Review N.S. 14: $73-100$. . 1991. "Free Traders and Free Immigrationists: Strangers or Friends?" Working Paper \# 20 (April), Russell Sage Foundation, N.Y. and T.N. Srinivasan. 1983. "On the Choice between Capital and Labour Mobility". JIE 14: $209-221$.

Christopher Bliss. 1994. "Trade blocks and migration", Chapter 5 in his Economic Theory and Policy for Trading Blocks. Manchester and New York: Manchester Univ. Press.

George J. Borjas. 1992. "Ethnic Capital and Intergenerational Mobility". QJE 107: 123-50. . 1993. "Tired, Poor, on Welfare". National Review (December). 1994. "The Economics of Immigration". JEL 32 (December): 1667-717. 1995a. "Ethnicity, Neighborhoods, and Human-Capital Externalities". AER 85 (3):365-90. 1995b. "The Economic Benefits from Immigration". J. Ec. Perspectives 9 (2): 3-22.

, R. B. Freeman and L.F. Katz. 1992. "On the Labor Market Effects of Immigration and Trade", in G. Borjas and R. Freeman (eds.), Immigration and the Work Force. Chicago: Univ.of Chicago Press.

P. Cashin and R. Sahay. 1996. "Internal Migration, Center-State Grants, and Economic Growth in the States of India." IMF Staff Papers 43 (1): 123-71.

Linda Chavez. 1993. "Immigration Politics". The International Economy (November-December).

Robert S. Chirinko. 1990. "Altruism, Egoism and the Role of Social Capital in the Private Provision of Public Goods". Economics and Politics 2 (3): 275-290.

James S. Coleman. 1987. "Norms as Social Capital", in G.Radnitzky and P.Bernholz (eds.) Economic Imperialism. The Economic Method Applied Outside the Field of Economics. New York: Paragon, pp. 133-53.

S120. 1988. "Social Capital in the Creation of Human Capital". American Journal of Sociology. 94 (1): S95-

1990. Foundations of Social Theory. Cambridge, Ma.: Harvard Univ. Press.

Donald R. Davis and D.E. Weinstein. 1997. "Does Economic Geography Matter for International Specialization?", Development Discussion Paper No. 591, HIID, Harvard Univ. (July).

S. Djajic and R. Milbourne. 1988. "A General Equilibrium Model of Guest-Worker Migration: The Source Country Perspective". Journal of International Economics 25: 335 - 351.

Avinash K. Dixit and V. Norman. 1980. Theory of International Trade. Cambridge: Cambridge Univ. Press.

Riccardo Faini and A. Venturini. 1993. "Trade, aid and migration. Some basic policy issues". Eur.Econ.Review 37: 435 442.

Joseph F. Francois. 1994. "Global Production and Trade: Factor Migration and Commercial Policy with International Scale Economies". IER 35 (3): 565 -580. 
Francis Fukuyama. 1993. "Immigrants and Family Values". Commentary (May).

Oded Galor and Oded Stark. 1990. "Migrants' Savings, the Probability of Return Migration and Migrants' Performance". IER 31 (2): 463 - 67.

. 1994. "Migration, Human Capital Formation, and Long-Run Output", in H. Siebet (ed.) Migration: A Challenge for Europe, Tubingen: Mohr.

Nadeem U. Haque and S.-J. Kim. 1995. "'Human Capital Flight'. Impact of Migration on Income and Growth". IMF Staff Papers 42 (3): 577-607.

Elhanan Helpman. 1984. "Increasing Returns, Imperfect Markets and Trade Theory", Chapter 7 in R.W.Jones and P.B. Kenen (eds.) Handbook of International Economics, Vol. 1, New York: North Holland.

Eliakim Katz and Oded Stark. 1984. "International Migration under Asymmetric Information". Economic Journal 97: 718 - 26 (reprinted in Stark 1991, Chapter 13).

Edward P. Lazear. 1995a. "Culture and Language". NBER Working Paper Series 5249 (September).

1995b. "Assimilation: 1900 and Now". Paper presented at the "Symposium on the Economic Analysis of Social Behaviour", convened by The Frazer Institute on the Occasion of Gary Becker's 65th Birthday, Chicago, Ill., December 1-2.

R. Layard, O. Blanchard, R. Dornbush and P. Krugman. 1992. East-West Migration. The Alternatives. Cambridge, Ma.: MIT Press.

Ramon Lopez and M. Schiff. 1998. "Migration and the Skill Composition of the Labor Force: The Impact of Trade Liberalization in LDCs." Canadian Journal of Economics.

Robert E.B. Lucas. 1987. "Emigration to South Africa's Mines". AER 77 (3): 314 - 30. James R. Markusen. 1983. "Factor Movements and Commodity Trade as Complements". JIE 14: 341-56. and Anthony J. Venables. 1988. "Trade Policy with Increasing Returns and Imperfect Competition: Contradictory Results from Competing Assumptions". JIE 24 (3/4): 299 - 316.

Douglas S. Massey, R. Alarcon, J. Durand, and H. Gonzalez. 1987. Return to Aztlan: The Social Process of International Migration from Western Mexico. Berkeley: Univ. of California Press.

A. Panagariya and M. Schiff. 1994. "Can Revenue Maximizing Export Taxes Yield Higher Welfare Than Welfare Maximizing Export Taxes?" Economics Letters 45: 79-84.

Robert D. Putnam. 1993. Making Democracy Work - Civic Traditions in Modern Italy. Princeton, N.J.: Princeton University Press.

Dani Rodrik. 1988. "Imperfect Competition, Scale Economies, and Trade Policy in Developing Countries", in R.E. Baldwin (ed.), Trade policy issues and empirical analysis. Chicago and London: University of Chicago Press.

Roy J. Ruffin. 1984. "International Factor Movements", Chapter 5 in R.W. Jones and P.B. Kenen (eds.) Handbook of International Economics, Vol. 1, New York: North Holland.

Peter V. Schaeffer. 1995. "The Work Effort and the Consumption of Immigrants as a Function of Their Assimilation". IER 36 (3): $625-42$.

Maurice Schiff. 1992a. "Social Capital, Labor Mobility, and Welfare: The Impact of Uniting States". Rationality and Society 4 (2): 157-175 (April).

1992b. "New Findings in the Theory of Optimal Congestion Taxes, with an Application to Road Transportation". Revista de Analisis Economico 6 (1): 81-92.

1995. "Trade Policy and International Migration in the Short and the Long Run". Revue d'economie du developpement: 3-25.

P. Stalker. 1994. The work of Strangers: A survey of International Migration. ILO: Geneva.

Oded Stark. 1991. The Migration of People. Oxford: Basil Blackwell.

Daniel Trefler. 1995. "The Case of the Missing Trade and Other Mysteries". AER 85 (5): 1029-47.

Anthony J. Venables. 1985. "International Trade, Trade and Industrial Policy, and Imperfect Competition: A Survey". CEPR Discussion Paper No. 74.

Dietmar Wellisch and Uwe Walz. 1998. "Why do rich countries prefer free trade over free migration? The role of the modern welfare state." European Economic Review 42: 1595-1612.

Klaus F. Zimmermann. 1995. "Tackling the European Migration Problem".J. Ec. Perspectives 9 (2): 45-62. 


\section{Table 1. Welfare Effect of Migration and Trade Policies*}

\author{
Individual Utility Maximization \\ I. Free Migration $-\mathrm{L}_{S}, \mathrm{~L}_{N}, \mathrm{M}$ are better off than with total \\ restriction on migration; $\mathrm{K}_{\mathrm{S}}$ and $\mathrm{K}_{\mathrm{N}}$ are \\ not affected; $\mathrm{N}$ and $\mathrm{S}$ lose.
}

Tariff in the South-- $\mathrm{L}_{\mathrm{S}}, \mathrm{L}_{\mathrm{N}}$ and $\mathrm{M}$ lose; $\mathrm{K}_{\mathrm{S}}$ gains, $\mathrm{K}_{\mathrm{N}}$ is unaffected; $\mathrm{N}$ and $\mathrm{S}$ lose.

Tariff in the North-- $\mathrm{L}_{\mathrm{S}}, \mathrm{M}, \mathrm{K}_{\mathrm{N}}$, and $\mathrm{N}$ and $\mathrm{S}$ lose; $\mathrm{K}_{\mathrm{S}}$ unaffected; effect on $L_{N}$ ambiguous.

Migration cost falls- $\mathrm{L}_{\mathrm{S}}, \mathrm{L}_{\mathrm{N}}$ and $\mathrm{M}$ lose; $\mathrm{K}_{\mathrm{S}}$ and $\mathrm{K}_{\mathrm{N}}$ unaffected; $\mathrm{N}$ and $\mathrm{S}$ lose.
Collective Welfare Maximization

$--\mathrm{L}_{\mathrm{S}}+\mathrm{M}\left(\mathrm{L}_{\mathrm{N}}\right)$ are better (worse) off than with total restriction on migration; $\mathrm{K}_{S}$ and $\mathrm{K}_{\mathrm{N}}$ unaffected; $\mathrm{S}(\mathrm{N})$ gains (loses).

$--\mathrm{L}_{S}+\mathrm{M}$ and $\mathrm{L}_{\mathrm{N}}$ lose; $\mathrm{K}_{\mathrm{S}}$ gains; $\mathrm{K}_{\mathrm{N}}$ unaffected; $\mathrm{N}$ and $\mathrm{S}$ lose.

$-\mathrm{L}_{\mathrm{S}}+\mathrm{M}$ gain; $\mathrm{K}_{\mathrm{S}}$ unaffected; $\mathrm{S}$ gains; $\mathrm{N}$ and $\mathrm{K}_{\mathrm{N}}$ lose; effect on $\mathrm{L}_{\mathrm{N}}$ ambiguous;

$--\mathrm{K}_{\mathrm{S}}, \mathrm{K}_{\mathrm{N}}$ unaffected; $\mathrm{L}_{\mathrm{S}}+\mathrm{M}$ gain; $\mathrm{L}_{\mathrm{N}}$ loses; $\mathrm{S}$ gains and $\mathrm{N}$ loses.

II. Migration Tax $--\mathrm{L}_{\mathrm{N}}$ is better off than with both free or no

$--L_{N}$ is better off than with both free or migration; $L_{S}$ and $M$ are better (worse) off than with free (no) migration; $K_{S}$ $\mathrm{K}_{\mathrm{N}}$ are unaffected. no migration; $L_{S}+M$ are worse (better) off than with free (no) and migration; $K_{S}$ and $K_{N}$ are unaffected.

Tariff in the South-- $\mathrm{L}_{S}$ and $M$ lose; $\mathrm{L}_{\mathrm{N}}$ gains; $\mathrm{K}_{\mathrm{S}}$ loses; $\mathrm{K}_{\mathrm{N}}$ is unaffected; $\mathrm{S}$ loses and $\mathrm{N}$ gains.

-- $\mathrm{L}_{\mathrm{S}}+\mathrm{M}$ loses; $\mathrm{L}_{\mathrm{N}}$ gains; $\mathrm{K}_{\mathrm{S}}$ gains; $\mathrm{K}_{\mathrm{N}}$ unaffected; $\mathrm{S}$ loses and $\mathrm{N}$ gains.

Tariff in the North -- $\mathrm{L}_{S}$ and $M$ lose; $\mathrm{L}_{\mathrm{N}}$ gains; $\mathrm{K}_{\mathrm{S}}$ is unaffected; -- $\mathrm{L}_{\mathrm{S}}+\mathrm{M}$ and $\mathrm{L}_{\mathrm{N}}$ gain; $\mathrm{K}_{\mathrm{S}}$ is unaffected; $K_{N}$ loses; $S$ loses; effect on $N$ ambiguous. $\quad K_{N}$ loses; $S$ gains; effect on $N$ is ambiguous.

Migration cost falls-- $\mathrm{L}_{S}$ and $M$ lose; $\mathrm{L}_{N}$ gains; $\mathrm{K}_{S}$ and $\mathrm{K}_{N}$ are $\quad--\mathrm{L}_{S}+\mathrm{M}$ and $\mathrm{L}_{N}$ gain; capital is not unaffected; $S$ loses and $\mathrm{N}$ gains. affected; $\mathrm{S}$ and $\mathrm{N}$ gain.

Illegal Migration---- All labor groups lose except for illegal --S gains and $\mathrm{N}$ loses (capital is migrants for whom the effect is ambiguous; unaffected). migrants as a whole lose; capital is unaffected; $\mathrm{S}$ and $\mathrm{N}$ lose.

* $\mathrm{L}_{S}\left(\mathrm{~L}_{\mathrm{N}}\right)$ are natives in the South (North); $\mathrm{M}$ are migrants; $\mathrm{K}_{\mathrm{S}}\left(\mathrm{K}_{\mathrm{N}}\right)$ is capital in the South (North); $\mathrm{S}(\mathrm{N})$ represents the South (North) as a whole. 
Figure 1

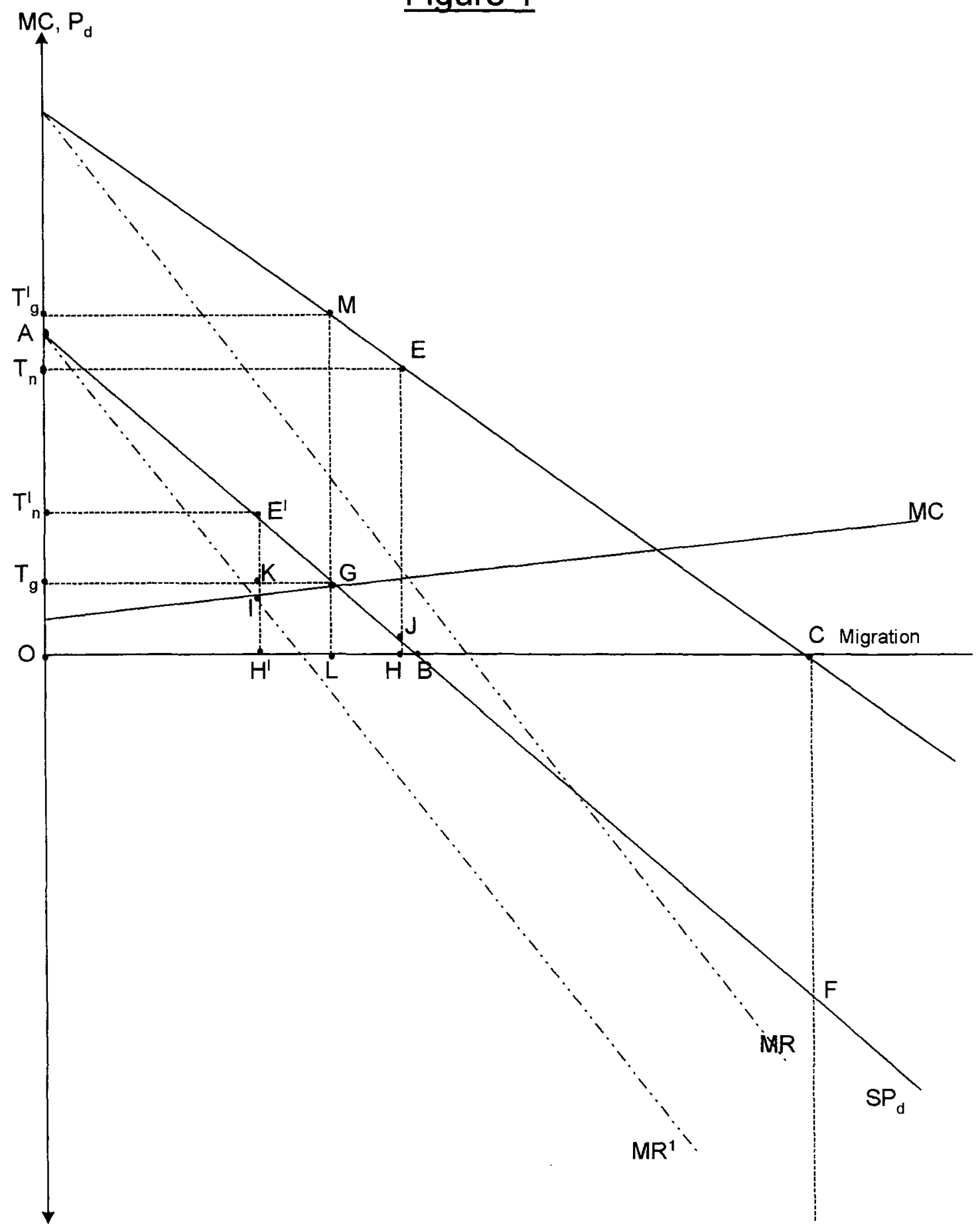




\section{Policy Research Working Paper Series}

Title

WPS2019 The Effects on Developing Countries of the Kyoto Protocol and Carbon

Dioxide Emissions Trading

WPS2020 Trade Liberalization, Fiscal Adjustment, and Exchange Rate Policy in India

WPS2021 Balance, Accountability, and Responsiveness: Lessons about Decentralization

WPS2022 The Implications of Foreign Aid Fungibility for Development Assistance

WPS2023 Capital Inflow Reversals, Banking Stability, and Prudential Regulation in Central and Eastern Europe

WPS2024 Re-Engineering Insurance Supervision

WPS2025 Dynamic Capital Mobility, Capital Market Risk, and Exchange Rate Misalignment: Evidence from Seven Asian Countries

WPS2026 Circuit Theory of Finance and the Role of Incentives in Financial Sector Reform

WPS2027 Child Labor: Cause, Consequence, and Cure, with Remarks on International Labor Standards

WPS2028 Access to Markets and the Benefits of Rural Roads

WPS2029 Small Manufacturing Plants, Pollution, and Poverty: New Evidence from Brazil and Mexico

WPS2030 The Political Economy of Financial Repression in Transition Economies

WPS2031 Addressing the Education Puzzle: The Distribution of Education and Economic Reform
Author

A. Denny Ellerman

Henry D. Jacoby

Annelene Decaux

Delfin S. Go

Pradeep Mitra

Anwar Shah

Date

Contact

for paper

Shantayanan Devarajan Vinaya Swaroop

Samuel Talley Marcelo M. Giugale Rossana Polastri

Lawrie Savage

Hong G. Min

Biagio Bossone

Kaushik Basu

Hanan G. Jacoby

Susmita Dasgupta

Robert E. B. Lucas

David Wheeler

Cevdet Denizer

Raj M. Desai

Nikolay Gueorguiev

Ramón López

Vinod Thomas

Yan Wang
December 1998

December 1998

December 1998

A. Shah 37687

December 1998

C. Bernardo 31148

December 1998

December 1998

T. Tourougui 87431

C. Bernardo 31148

December 1998

M. Geller 85155

December 1998

H. Arbi

34663

December 1998

K. Labrie 31001

December 1998

B. Bossone 33021

M. Mason 30809

M. Fernandez 33766

December 1998

Y. D'Souza 31449

December 1998 T. Hailu 44396

December $1998 \quad T$. Shiel 36317 


\section{Policy Research Working Paper Series}

\section{Title}

WPS2032 Institutional Investors and Securities Markets: Which Comes First?

WPS2033 Diversification and Efficiency of Investment by East Asian Corporations

WPS2034 Information, Accounting, and the Regulation of Concessioned Infrastructure Monopolies

WPS2035 Macroeconomic Uncertainty and Private Investment in Developing Countries: An Empirical Investigation

WPS2036 Vehicles, Roads, and Road Use: Alternative Empirical Specifications

WPS2037 Financial Regulation and Performance: Cross-Country Evidence

WP\$2038 Good Governance and Trade Policy: Are They the Keys to Africa's Global Integration and Growth?

WPS2039 Reforming Institutions for Service Delivery: A Framework for Development Assistance with an Application to the health, Nutrition, and Population Portfolio

\section{WPS2040 Making Negotiated Land Reform} Work: Initial Experience from Brazil, Colombia, and South Africa

WPS2041 Aid Allocation and Poverty Reduction $\begin{aligned} & \text { Paul Collier } \\ & \text { David Dollar }\end{aligned}$
$\begin{array}{ll}\text { WPS2042 Determinants of Motorization and } & \begin{array}{l}\text { Gregory K. Ingram } \\ \text { Zhi Liu }\end{array} \\ \text { Road Provision } & \text { Menno Pradhan } \\ \text { PW2043 Demand for Public Safety } & \text { Martin Ravallion }\end{array}$

Dimitri Vittas

Stijn Claessens Simeon Djankov Joseph P. H. Fan Harry H. P. Lang

Phil Burns Antonio Estache

Luis Servén

Gregory K. Ingram Zhi Liu

Gerard Caprio, Jr. Ross Levine

Francis $\mathrm{Ng}$ Alexander Yeats
Contact Date for paper

December 1998

December 1998

A. Yaptenco 38526

December 1998

December 1998

H. Vargas 38546

December 1998

J. Ponchamni 31022

January 1999

A. Yaptenco 38526

January 1999

L. Tauada 36896

January 1999

B. Casely-Hayford 34672

January 1999

M. Fernandez 33766

January 1999

E. Khine 37471

January 1999

J. Ponchamn 31022

January 1999

P. Sader 33902 